\title{
Analysis of Microbial Contamination in Oreochromis Niloticus in Waduk Muara Nusa Dua
}

\author{
Ni Kadek Peniasih ${ }^{1}$, I Gede Suranaya Pandit ${ }^{2}$, Dewa Gede Semara Edi ${ }^{3}$ \\ ${ }^{1,2,3}$ Fisheries Resource Management Study Program, Faculty of Agriculture, Warmadewa University, \\ Indonesia \\ *Corresponding author: suranaya_pandit@yahoo.com
}

\begin{abstract}
This study aims to determine the microbiological contamination in the main water source of the Muara Nusa Dua Reservoir, the Tukad Badung River, and to determine the microbiological quality of fresh Oreochromis niloticus caught in the Muara Nusa Dua Reservoir in Denpasar. The study was conducted in May-August 2019 at the Denpasar Veterinary Laboratory. The method used is a descriptive method that aims to describe or describe the condition of the Tukad Badung watershed which empties into the Muara Nusa Dua Reservoir (Estuary Dam). Objective tests include the total bacterial test, the Coliform test, and the Escherichia coli contamination test. Water quality measurements are also carried out as supporting data from this study. The results of the study stated that there was microbiological contamination in the water source of the Muara Nusa Dua Reservoir, the Tukad Badung river, which also had an impact on the waters of the Muara Nusa Dua Reservoir. Microbiological contamination research results showed the microbiological quality of ten samples of Oreochromis niloticus in the form of the highest total bacteria was at $2.2 \times 10^{4}$, the highest total Coliform was $1.9 \times 10^{4}$ and the highest Escherichia coli contamination was at $93 \mathrm{APM} / \mathrm{g}$ with an average reservoir water quality Muara Nusa Dua in the form of temperature $27.3{ }^{\circ} \mathrm{C}$, salinity $0.208 \%$, degree of acidity $(p H) 6.5$, dissolved oxygen (DO) 5,97 ppm. Organoleptic observations included the appearance, smell, and texture of Oreochromis niloticus with good results because when testing Oreochromis niloticus is still alive
\end{abstract}

Keywords: Muara Nusa Dua reservoir, Oreochromis niloticus, microbiological contamination

\section{Introduction}

The use of common-pool natural resources tends to create conflicting interests in the community. The economic rent that is obtained is often the main reason to set aside environmental sustainability which backfires for the utilization of the resource itself. One form of common-pool resource is a reservoir, which is a form of inland water beside rivers and lakes. Reservoirs are artificial lakes formed through the construction of dams that cut the flow of some rivers or are built on lake outlet channels or natural reservoirs that function to control reservoir water levels [1].

Indonesia has several reservoirs scattered in each region, one of which is the Muara Nusa Dua Reservoir which is located in Pemogan Village, South Denpasar District, Bali Province. It has a 35hectare puddle area with a depth of approximately four meters during normal conditions and can reach a depth of five meters at high tide. The Muara Nusa Dua Reservoir area is one of the places that have the potential to become a water tourism area. Beautiful, cool, and natural scenery in the middle of Denpasar city can be an important point for its development. In addition to fishermen, local people often use this reservoir area as a place of worship, fishing, recreation, and trading. Fishing is done every day by the local fishermen and the surrounding community. There are several types of fish caught, ranging from surface fish such as Oreochromis niloticus, Oreochromis 
niloticus fish, and carp to basic fish such as broom fish and cork fish, but for the dominant consumption fish caught are Oreochromis niloticus.

On the other hand, the location of the Muara Nusa Dua Reservoir at the mouth of the Tukad Badung River has several negative impacts, such as siltation and water pollution by waste which can cause contamination of water and organisms contained in these waters. Baduk Tukad has a river flow length of $27 \mathrm{~km}$ with a maximum water discharge of $6.01 \mathrm{~m}^{3} / \mathrm{sec}$ and a minimum of $1.44 \mathrm{~m}^{3} / \mathrm{sec}$ is the main source of river water flow into the Muara Nusa Dua Reservoir and enters Denpasar City after flowing from the Badung Regency. Muara Nusa Dua Reservoir also becomes raw water for Denpasar PDAM which is treated and serves the needs of clean water in South Denpasar [2]. Thus, the quality of the estuary water of the Tukad Badung River is important to be considered, considering that the condition is somewhat polluted by waste disposal from various rural and urban activities. Reporting from the Bali Provincial Environment Office in 2018, stated a significant change in the river pollution index in Badung Regency. One of them is the Tukad Badung river which is stated as having a polluted status and has been polluted within the last three years. Activities both in the watershed and in the waters of Tukad Badung are growing rapidly and directly. The various activities are settlement with various daily activities, agriculture (upstream), livestock, workshop, laundry, market, hospital, food industry, handicraft, office building, and direct access to river water for MCK. These various activities produce waste which directly or indirectly overloads the waters so that it will affect the condition and function of the waters going forward.

Fish is a food ingredient that contains a lot of protein and has been consumed by humans since several centuries ago. Fish is widely known for being a side dish that is easily obtainable at an affordable price and has a high nutritional value, but fish is a perishable food, causing a nutritional value to decrease easily [3]. The freshness of fish is very important in determining the overall quality of a fishery product. The quality of freshness can include appearance or appearance, odor, color, taste, and texture that are consciously or unconsciously assessed by consumers of the product [4]. The contamination of fish arises due to unbalanced interactions between the host, the environment, and pathogens. One of the pathogens that cause disease that attacks fish is microbes [5].

Seen from the environment, fish is a food that comes from water media, where water is a Coliform infection media. Coliform is a group of gram-negative rod-shaped bacteria that generally produce gas if grown in a lactose medium. The higher the level of contamination of Coliform bacteria, the higher the risk of the presence of other pathogenic bacteria that can live in an environment or food. One example of pathogenic bacteria that may be present in contaminated water, human waste, or warm-blooded animals is the Escherichia coli bacteria, which are microbes that cause digestive tract infections, symptoms of diarrhea, fever, stomach cramps, and vomiting [6]. Because Escherichia coli is a Coliform bacteria present in human waste, Escherichia coli is often referred to as an indicator bacterium or an early sign of contamination by other pathogenic bacteria [7]. If food is found in Coliform fecal, it means that the food and environment have been contaminated by human or animal waste, so that consuming food that has been contaminated with Escherichia coli can cause an increase in these bacteria in the human intestine which can cause diarrhea and other digestive system disorders.

Therefore it is necessary to test the quality of microbial contamination in the water source of the Muara Nusa Dua Reservoir and Oreochromis niloticus caught in the Muara Nusa Dua Reservoir so that it can be used as an alternative by the community and the government as a basis for management so that pollution and environmental damage to the reservoir waters Muara Nusa Dua can be minimized and the potential of available resources can be maintained. 


\section{Material and Methods}

\subsection{Place and Time}

The study was conducted in the Tukad Badung River, Muara Nusa Dua Reservoir in Denpasar, and the Denpasar Veterinary Center Laboratory. The study was conducted for 4 months, from MayAugust 2019.

\subsection{Research Material}

The raw materials used in this study are Tukad Badung river water and Oreochromis niloticus fish caught in the Muara Nusa Dua Reservoir in Denpasar. Oreochromis niloticus is used as many as 10 fish from two repetitions. The chemicals used in the analysis were equated, $70 \%$ alcohol, Lauryl Sulfate Typtose Broth, Plate Count Agar (PCA), BPW 0.1\% solution, spiritus, Brilliant Green Lactose Bile Broth (BGLBB), Escherichia coli broth (ECB).

The tools used for microbial contamination analysis in this study are vortex, test tube rack, test tube, oven, digital balance, spiritus lamp, tweezers, styrofoam box, volume pipette, laminar flow, Erlenmeyer Flask, one needle, incubator, measuring cup, autoclave, and aluminum foil.

\subsection{Research Methods}

This research uses descriptive research. Descriptive research is research that aims to describe (describe) phenomena found using survey methods, both in the form of risk factors, as well as an effect or outcome. The results of this study are observations regarding the level of contamination and the quality of pathogenic microbial contamination, namely total bacteria, total Coliform and Escherichia coli in reservoir water sources, and Oreochromis niloticus fish caught by fishermen in Muara Nusa Dua Reservoir. Research method.

\subsection{Research Implementation}

The implementation phase of the research starts with surveying in advance to the location of the study. Then conducted activities in the field in the form of water sampling from the Tukad Badung river and Oreochromis niloticus in the Muara Nusa Dua Reservoir. Furthermore, water samples are measured for water quality. after the field activities are finished, water and Oreochromis niloticus samples are stored in a styrofoam box and immediately taken to the laboratory by road within 15 minutes of travel and the fish are still alive when they arrive at the laboratory for microbial contamination testing in the form of total bacteria, total coliforms, and E. coli.

\subsection{Research Variables}

Research variables are anything in the form of what is determined by researchers to be studied so that information is obtained for it, then the conclusions are drawn [8]. In this study, the main variables to be investigated, namely the presence of microbial contamination in the form of total bacteria, Coliform and E.coli in Oreochromis niloticus caught in the Muara Nusa Dua Reservoir.

\subsection{Data Analysis}

The data analysis technique in this study uses a comparison of the results of research with the value of the Indonesian National Standard (SNI 7388: 2009) established by BPOM RI Number HK.00.06.1.52.4011 in 2009 concerning the maximum limit of microbial contamination in fishery products supported by regulations The Minister of Maritime Affairs and Fisheries Republic of Indonesia Number PER.19/MEN/2010 concerning controlling the quality assurance system and safety of fishery products. 


\section{Results and Discussion}

\subsection{Objektive Variable}

Objective test results are test results based on facts or facts that are not mixed with personal opinions (feelings) that are subjective. Objective test results in this study include microbiological analysis consisting of analysis of total bacteria, total Coliform, and Escherichia coli contamination as well as organoleptic observation data and water quality as supporting data in this study.

\subsubsection{Microbial Contamination in Reservoir Water Sources}

Tukad Badung has a length of $27 \mathrm{~km}$ with a maximum water discharge of $6.01 \mathrm{~m}^{3} / \mathrm{s}$ and a minimum of $1.44 \mathrm{~m}^{3} / \mathrm{s}$. Baduk Tukad is a meeting between six other rivers, among others: Tukad Langan, Tukad Medih, Tukad Gorge, Tukad Guming, Tukad Ketapian, and Tukad Kelandis. Tukad Madung river flows through various rural and urban activities. Rural activities such as agriculture, plantation, and animal husbandry. While urban activities such as industry and hospitals. The results of testing microbial contamination in Sugai Tukad Badung water can be seen in the following Table 1.

Table 1

Value of Total Bacteria, Total Coliform, and E.coli Contamination in Tukad Badung River Water

\begin{tabular}{cccccc}
\hline \multirow{2}{*}{ No } & $\begin{array}{c}\text { Type of } \\
\text { Sample }\end{array}$ & Sample Code & \multicolumn{3}{c}{ Microbial Contamination } \\
\cline { 4 - 5 } & & $\begin{array}{c}\text { Total Bacteria } \\
(\text { colony/ml })\end{array}$ & $\begin{array}{c}\text { Total Coliform } \\
(\text { APM/ml })\end{array}$ & $\begin{array}{c}\text { E.coli Contamination } \\
(\text { APM/ml })\end{array}$ \\
\hline 1 & Water & Upstream & $1.6 \times 10^{5}$ & $>1100$ & 460 \\
2 & Water & The middle & $1.3 \times 10^{5}$ & $>1100$ & 210 \\
3 & Water & Downstream & $1.2 \times 10^{5}$ & $>1100$ & 93 \\
\hline
\end{tabular}

Based on the results of research that has been obtained, it is true that the bacteria found in a source of reservoir water, namely Tukad Badung, are Coliform bacteria, namely Escherichia coli.

\subsubsection{Total Bacteria in Oreochromis Niloticus}

The number of bacteria uses the Total Plate Count (TPC) method to determine the number of mesophile aerobic bacteria, which are bacteria that metabolize with the help of oxygen and bacteria that live in temperatures between $15-55^{\circ} \mathrm{C}$, with an optimum temperature of $25-40{ }^{\circ} \mathrm{C}$ in food and beverages. The media used in the bacterial count test is the Plate Count Agar (PCA). From the results obtained in this test, that the total bacteria in the Oreochromis niloticus with the highest yield was found at the location of the first Oreochromis niloticus fishing sample testing in the northern part of the reservoir with a total bacteria of $2.2 \times 10^{5}$ colonies/g. Whereas the lowest yield was found at the location of Oreochromis niloticus fishing in the southern part of the reservoir with a total bacteria of 1.0x 104 colony/g in the second replication sample test.

\subsubsection{Total Coliform}

The results of a Coliform analysis comparison of ten Oreochromis niloticus samples obtained from two repetitions of Oreochromis niloticus sampling at the Muara Nusa Dua Reservoir at different times are presented in Figure 1. From the results shown on Figure 1, it can be seen that the total Coliform in captured Oreochromis niloticus in the Muara Nusa Dua Reservoir, with the highest yield found in the first sample testing Oreochromis niloticus at fish sampling sites located in the southern part of the reservoir, is $1.9 \times 10^{4}$ colonies/g. Whereas the lowest yield is found in the 
location of Oreochromis niloticus sampling in the east and middle of the reservoir obtained during the repetition of the second sample with the same total Coliform value of $1.1 \times 10^{3}$ colony/g.

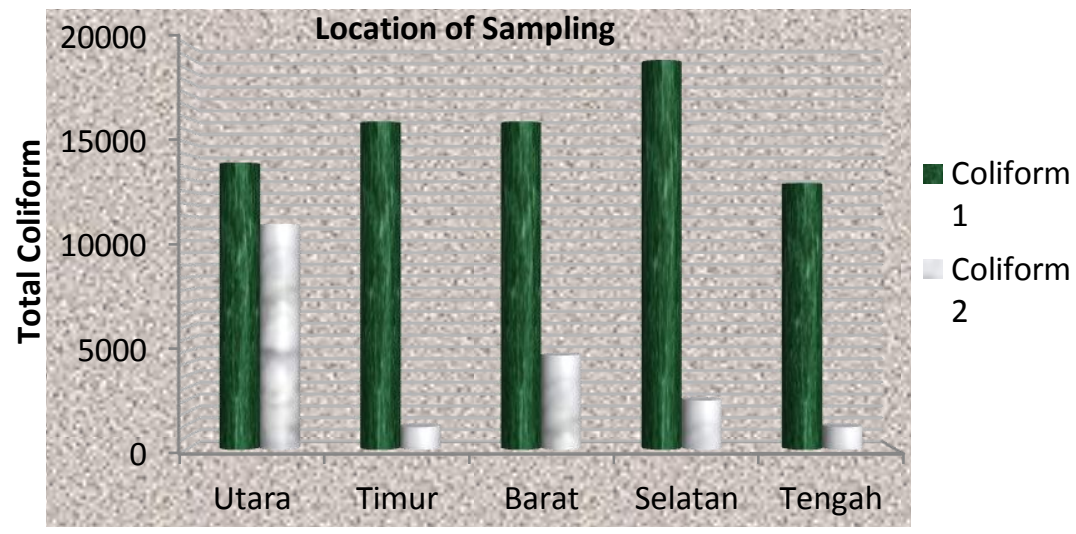

Figure 1.

Comparison of total coliform at the location of Oreochromis niloticus sampling

\subsubsection{E.coli Contamination}

Fish samples were tested using the Most Probable Number (MPN) method with series 3 tubes each dilution. The test is carried out by the estimation test and the affirmation test without isolation-identification because all it takes is the total value of the total E.coli contamination in the $10 \mathrm{~g}$ sample of the Oreochromis niloticus. From the E.coli contamination test results shown on the graph, it can be seen that E.coli contamination in Oreochromis niloticus caught in the Muara Nusa Dua Reservoir with the highest results is in the first sample test where the capture location is located in the southern part of the reservoir with contamination values, namely $93 \mathrm{APM} / \mathrm{g}$, while the lowest E. coli contamination value is found in the second sample test in the central, southern and eastern reservoirs with a contamination value $<3 \mathrm{APM} / \mathrm{g}$. The results of research on microbial contamination in the form of total bacteria, total Coliform, and E.coli contamination can be seen in detail in Table 2.

Table 2

Value of Total Bacteria, Total Coliform and Contamination E.coli in Fresh Oreochromis Niloticus

\begin{tabular}{ccccccccc}
\hline & & & \multicolumn{3}{c}{ Microbial Contamination } \\
\cline { 4 - 8 } No & $\begin{array}{c}\text { Type of } \\
\text { Sample }\end{array}$ & $\begin{array}{c}\text { Sample } \\
\text { Code }\end{array}$ & $\begin{array}{c}\text { Total Bacterial } \\
\text { (colony/g) }\end{array}$ & $\begin{array}{c}\text { Total Coliform } \\
\text { (colony/g) }\end{array}$ & $\begin{array}{c}\text { E.coli } \\
\text { Contamination } \\
\text { (APM/g) }\end{array}$ \\
\cline { 4 - 9 } & & & I & II & I & II & I & II \\
\hline 1 & O.Niloticus & A & $2.2 \times 10^{5}$ & $1.6 \times 10^{5}$ & $1.4 \times 10^{4}$ & $1.1 \times 10^{4}$ & 11 & 9.4 \\
2 & O.Niloticus & B & $2.2 \times 10^{5}$ & $2.4 \times 10^{4}$ & $1.6 \times 10^{4}$ & $1.1 \times 10^{3}$ & 9.4 & $<3$ \\
3 & O.Niloticus & C & $1.7 \times 10^{5}$ & $1.6 \times 10^{5}$ & $1.6 \times 10^{4}$ & $4.6 \times 10^{3}$ & 9.2 & 3.6 \\
4 & O.Niloticus & D & $2.1 \times 10^{5}$ & $1.0 \times 10^{4}$ & $1.9 \times 10^{4}$ & $2.4 \times 10^{3}$ & 93 & $<3$ \\
5 & O.Niloticus & E & $1.8 \times 10^{5}$ & $2.2 \times 10^{4}$ & $1.3 \times 10^{4}$ & $1.1 \times 10^{3}$ & 23 & $<3$ \\
\hline
\end{tabular}

\footnotetext{
*Information:

$\mathrm{A}=$ Location I is fish sampling which is the northern part of the Muara Nusa Dua Reservoir $\mathrm{B}=$ Location II is fish sampling which is the eastern part of the Muara Nusa Dua Reservoir $\mathrm{C}=$ Location III is fish sampling which is the western part of the Muara Nusa Dua Reservoir $\mathrm{D}=$ Location IV is fish sampling which is the southern part of the Muara Nusa Dua Reservoir $\mathrm{E}=$ Location $\mathrm{V}$ is fish sampling which is the middle part of the Muara Nusa Dua Reservoir
} 
Based on the results of research conducted at the Denpasar Veterinary Laboratory, the results of the water source in Muara Nusa Dua Reservoir, whose main water source comes from the Tukad Badung River in Table 1, it appears that microbial contamination is evident from the growth of the anchovy colony in total testing. bacteria in the three river water samples. The presence of Coliform and E.coli in the Tukad Badung river water shows that the river water has been contaminated with human and animal feces from upstream to downstream of the river so that it is indicated that the river water management is ineffective. Judging from the data of the Bali Provincial Environment Office in 2018 about the trend of the Tukad Badung river water pollution index in the last three years the status has changed from meeting the quality standards to being polluted while with a pollution index value of 9.13 caused by several aspects including technical aspects and social aspects. Technical aspects include increased sedimentation rates, cliff/embankment damage due to scouring of foundations, and flood discharges which have large fluctuations during the rainy season. While from the social aspects include the behavior of people who experience degradation in disposing of waste $40 \mathrm{~m}^{3} / \mathrm{day}$ during the dry season and tenfold increase during the rainy season, land values are increasingly expensive so that it takes up the border of the river area for settlements as well as community needs for community activities such as MCK.

Tukad Badung River water flows as the main water source that flows and empties into the Muara Nusa Dua Reservoir (Estuary Dam) certainly has a significant impact on water conditions from upstream to downstream of the reservoir. The research that was produced using fresh Oreochromis niloticus (Oreochromis niloticus) fish caught at Wadauk Muara Nusa Dua from two repeated sampling and organoleptic quality samples obtained an average score of 9 so that it was still classified as good because the fish were still alive when it arrived at the laboratory. From the results of total bacterial testing from 10 samples of Oreochromis niloticus tested, all Oreochromis niloticus tested were still meeting Indonesian National Standards (SNI 7388: 2009) with the total bacterial colony still below $5 \times 10^{5}$ for fresh Oreochromis niloticus. While the total Coliform test results were obtained from 10 samples of Oreochromis niloticus, 6 of them did not meet the Indonesian National Standard [9] ie their presence exceeded $1.0 \times 10^{4}$, while the other 4 samples still meet these standards. The results of research on E.coli contamination, from 10 samples tested, 7 of them have exceeded the contamination limit set by the Indonesian National Standard [9] with a maximum contamination limit of $<3$ APM/g following the provisions of BPOM HK.00.06 1.52.4011 concerning setting limits on microbial and chemical contamination in food, while 3 of them still meet established standards.

The samples studied were taken from five different locations following the presence of fishermen or local people who catch fish and are considered to have represented the entire area of the Muara Nusa Dua Reservoir. Fish samples were taken at different periods viz \pm 2 months, i.e. sampling of the first test fish was conducted in May and the second test in July. Unintentionally the southern reservoir gate was closed at the time of the first replication sampling and was open at the time of the second replication sample. The situation has an influence on the results of microbial contamination testing on Oreochromis niloticus with the results of the study showed the average higher contamination value was in the sample of the first replica Oreochromis niloticus, if it was related to water conditions, water discharge affected the increase in the number of bacterial colonies in water. Higher water discharge allows a higher impact of microbial contamination compared to low water discharge.

Community behavior also influences the quality of microbiologists from upstream to downstream. Most of the people in the upper reaches are less or most have not ignored the government regulation to treat waste before being discharged into the waters like feces, the upstream community still uses the river flow to dispose of feces directly or indirectly, while urban communities are not allowed to do so. Any waste that will be discharged into the water must be 
treated first with a dilution that has been recommended to reduce the presence of pathogenic microbes in the waters. Besides, the reservoir condition which is inundated with a lot of garbage also triggers the arrival of flies or other insects as an intermediary to expand the spread of diseasecausing bacteria. Dense piles of garbage and mud cause siltation in the reservoir area, it shows that the lack of maintaining cleanliness and public awareness to protect the environment (water sources) from pollutants and waste that can adversely affect health.

Test results in this study indicate that the majority of positive Oreochromis niloticus samples were contaminated with Coliform bacteria. Coliform is often used as an indicator of determining water quality, the presence of Coliform bacteria in water sources and aquatic organisms is a signal to determine a water source has been contaminated by pathogenic bacteria, so in this study proceed to the testing phase of E.coli contamination. The existence of E. coli is an indicator of bacteria as a signal or an initial phenomenon to reveal the presence of other pathogenic bacteria in Tukad Badung and the Muara Nusa Dua Reservoir and will be a problem for other researchers to uncover more deeply.

\section{Conclusion}

Based on the results of microbiological contamination in the water source of Muara Nusa Dua Reservoir, namely the Tukad Badung River and fresh Oreochromis niloticus (Oreochromis niloticus) caught in Muara Nusa Dua Reservoir, it can be concluded that there are microbial contaminants in the form of total bacteria, total Coliform and E.coli contamination in the reservoir water flow namely the Tukad Badung River and the results of the study were obtained from a total of ten fresh Oreochromis niloticus samples obtained in two sampling repeats guided by SNI 7388: 2009 and BPOM HK.00.06.1.52.4011 concerning setting limits Microbial contamination in fresh Oreochromis niloticus (Oreochromis niloticus), shows that for a total of ten bacteria the fresh Oreochromis niloticus samples still meet the established standards of $5 \times 10^{5}$ colony/g and has not yet exceeded the threshold for total bacterial presence in fresh Oreochromis niloticus. While the results of research on total Coliform, from ten samples of fresh Oreochromis niloticus, six of them contained Coliform bacteria whose presence exceeds the maximum threshold of their presence in fresh Oreochromis niloticus namely $1 \times 10^{4}$ colony/g. While E Coli contamination from ten samples of fresh Oreochromis niloticus, seven of them showed the value of contamination exceeded the maximum threshold that has been set that is past the value $<3 \mathrm{APM} / \mathrm{g}$.

\section{References}

[1] Anonimus (2010). Panduan Valuasi Ekonomi Ekosistem Danau/Waduk. Kementerian Lingkungan.

[2] Anonimus (2006). Data Tren Indeks Pencemaran Air Sungai. Dinas Lingkungan Hidup. Bali

[3] Buckle K A. (1987). Ilmu Pangan. Universitas Indonesia Press. Jakarta.

[4] Winarni T, Swastawati F, Darmanto Y S \& Dewi E N. (2003). Uji Mutu Terpadu pada Beberapa Spesies Ikan dan Produk Perikanan di Indonesia. Laporan Akhir Hibah Bersaing XI Perguruan Tinggi. Universitas Diponogoro. Semarang.

[5] Azhari C, Tumbol R A \& Kolopita M E F. (2014). Diagnosa penyakit bakterial pada ikan Nila (Oreocromis niloticus) yang dibudidayakan pada jaring tancap di Danau Tondano. Jurnal Budidaya Perairan. 2(3): 24-30.

[6] Entjang I. (2003). Mikrobiologi dan Parasitologi Untuk Akademi Keperawatan dan Sekolah Tenaga Kesehatan yang sederajat, 58-61. PT. Citra Aditya Bakti. Jakarta.

[7] Pandit I G S, Suryadhi N T, Arka I B \& Adiputra N. (2012). Pengaruh penyiangan dan suhu penyimpanan terhadap mutu kimiawi, mikrobiologis dan organoleptik ikan tongkol (Auxis tharzard, Lac). Universitas Warmadewa.

[8] Sugiyono (2010). Statistika Untuk Penelitian. Bandung: Alfabeta

[9] Badan Standarisasi Nasional (2009). Batas maksimum cemaran mikroba dalam pangan, Standar Nasional Indonesia, SNI 7388:2009. Jakarta. 